\title{
The Role of the Disaster Preparedness Group in Adapting Abrasion to Communities Affected by Abrasion on the North Coast of Rembang, Central Java
}

\author{
Dewi Liesnoor Setyowati ${ }^{1, *}$ Puji Hardati ${ }^{2}$, Andi Irwan Benardi ${ }^{3}$ Nur Hamid ${ }^{4}$, \\ Yohanes Dwi Anugrahanto 5 \\ ${ }^{1,2,3}$ Department of Geography, Faculty of Social Sciences, Universitas Negeri Semarang \\ ${ }^{4}$ Islamic Community Development Study Program, Walisongo State Islamic University Semarang \\ ${ }^{5}$ Master Student of Geography Education Study Program, Universitas Negeri Semarang \\ *Corresponding author. Email: liesnoor2015@mail.unnes.ac.id
}

\begin{abstract}
Disaster mitigation efforts through increased vigilance and preparedness must be sustained. The Disaster Preparedness Group (KSB) is a partner of the BPBD of Rembang City in disaster risk reduction. People who are members of KSB in areas prone to abrasion disasters are still pretty much clueless about abrasion disaster mitigation efforts. Public ignorance of disasters can result in losses that will befall residents. KSB has a vital role in providing information and assistance for the surrounding community. The research objectives were 1) to determine the incidence of abrasion in Kragan Village, 2) to analyze the role of KSB in handling and adapting the community to abrasion disasters. A qualitative approach is used in this research. The research focused on the activities and roles of KSB in handling coastal abrasion. Research informants include family heads who live in abrasion-prone areas, village heads, and community leaders. The results showed that the KSB, during a disaster and pre-disaster, had a role in providing socialization and education to the community. However, this activity still encountered obstacles, so that it was not yet effective. The obstacles include the absence of operational funds for activities owned by the Disaster Preparedness Group, no supporting facilities and infrastructure for activities, the existence of conditions where some members do not care, and the condition of the people in the area. The role of the community in self-supporting coastal management in reclamation has various challenges, particularly in the aspects of funding, mindset, infrastructure, and community participation, that need solutions.
\end{abstract}

Keywords: Disaster Mitigation, Disaster Preparedness, Disaster Education, Abrasion.

\section{INTRODUCTION}

Rembang Regency is one of the districts in Central Java that has a high vulnerability to disasters. Various disasters such as floods, landslides, earthquakes, and abrasion have occurred in Rembang Regency [1]. Especially in abrasion, the area most prone to being affected is in five districts, namely Kaliori District, Rembang District, Lasem District, Sluke District, Sarang District, and Kragan District [2]. Kragan Subdistrict is a sub-district that has experienced the most severe impact compared to the other four subdistricts, where there were at least nine times abrasions in the last nine years from 2012 to 2020 or it means that the average abrasion disaster occurs every year as shown in Table 1. Based on the results of processing data obtained by the Regional Agency for Disaster Management (BPBD), it was noted that the abrasion disaster caused material losses of at least IDR 889 million along with indirect impacts, such as obstructed social activities of communities and unfulfilled community food needs. 
Table 1. Abrasion Disaster in Kragan District, 2012-2020

\begin{tabular}{cccc}
\hline No. & Year & Village & Loss \\
\hline 1. & 2012 & Kragan & Rp. 89.000.000 \\
2. & 2013 & Kragan & - \\
3. & 2013 & Sumurtawang & - \\
4. & 2014 & Tanjungan & Damage up to 235 meter long \\
5. & 2016 & Karangharjo & Damage up to 250 meter long \\
6. & 2017 & Tegalmulyo & Damage up to 250 meter long \\
7. & 2018 & Karangharjo & Rp. 200.000.000 \\
8. & 2019 & Kragan & Rp. 600.000.000 \\
9. & 2019 & Pandangan &
\end{tabular}

Source: BPBD of Rembang Regency, 202

The high vulnerability of abrasion in Kragan Subdistrict has not been followed by adequate knowledge, attitudes, and community skills in dealing with this disaster. Based on the observations conducted, it is known that the community is still carrying out various activities that can trigger disasters, such as mining sand and rocks, cutting down mangroves, and reluctance to take mitigation and adaptation efforts to prevent disasters from occurring. People even still use a conventional point of view, where they position themselves as "objects" who are victims of abrasion, not as "subjects" who seek to prevent abrasion by first increasing their knowledge and capacity in dealing with abrasion disasters [3].

Therefore, there need to be efforts to raise awareness and increase knowledge and capacity of disasters to the community through disaster education [4]. Disaster education can be provided both before and after a disaster occurs. Before a disaster occurs, disaster education will be very effective in building community awareness and preparedness [5], [6]. After and before a disaster, providing disaster education will increase the community's capacity in dealing with disasters that will occur again [7], [8]. Disaster education provided after a disaster, such as in Kragan Village, Kragan District, enables people to learn about disasters based on contextual experiences [9]. Disaster education given contextually based on directly experienced problems will be easier to understand and apply in everyday life [10], [11].

One of the parties that play an essential role in providing disaster education to the community is higher education as a formal education institution [4]. One of these efforts can be made through the Disaster Preparedness Group (KSB) program. The implementation of the KSB is expected to increase the knowledge, attitudes, and skills of the Kragan Village community in dealing with abrasion disasters. The implementation of KSB certainly requires quite a long time and with the assistance of experts because building the mindest of the community to have mastery over disasters must be done in a structured, massive, and systematic manner [12]. The continuity of the KSB work program that is sustainable from generation to generation will produce Kragan Village that is alert in the face of abrasion disasters. The research objectives were 1) identifying the incidence of abrasion in Kragan Village and 2) analyzing the role of KSB in handling and adapting the community to abrasion disasters.

\section{METHODS}

A qualitative approach was used in this research. The research subjects were people affected by the abrasion disaster. The research locations include 13 villages along the Kragan coast affected by coastal hazards, divided into fishing villages and non-fishing villages. A purposive sampling system was used to extract information that can meet the research objectives. The research focused on the activities and roles of KSB in handling coastal abrasion and losses due to abrasion. The primary informants of the study include heads of families who live in areas prone to abrasion, while the key informants are village heads and community leaders.

Data collection was carried out through observation, questionnaires, and interviews. Observations were conducted by observing the abrasion location, including the range of abrasion, physical and non-physical impacts, handling efforts, and community behavior in the coastal area. Secondary data includes data on the incidence of abrasion and tidal waves, data on damage, data on disaster management, and data on water characteristics and coastal social and physical characteristics. Data from interviews and observations were analyzed using descriptive qualitative. 


\section{RESULTS AND DISCUSSION 3.1.Abrasion Disaster in Kragan Village}

The types of hazards that occur in coastal areas are abrasion, accretion, and tidal waves. Damage is divided into damage to land, settlements, and public facilities. Kragan Subdistrict, Rembang Regency is also prone to them. Disaster risk is influenced by hazard, vulnerability, and community capacity - the dynamic processes influence coastal hazards. The Kragan coastal community consists of fishers, farmers, and fish

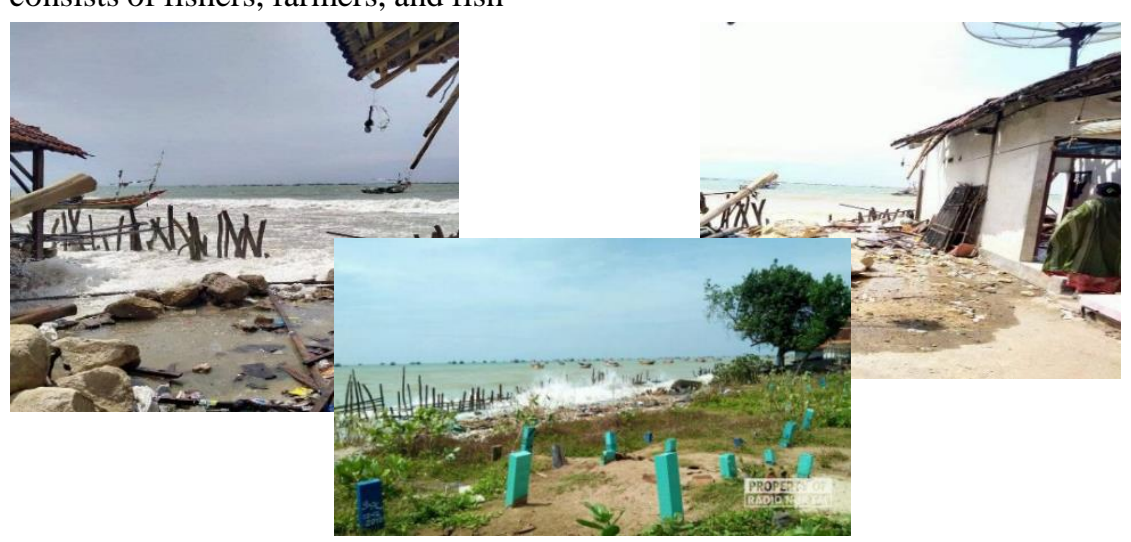

farmers. Residents along the coastal area of View
Village in Kragan Subdistrict cannot sleep soundly every time the eastern climate arrives. The waves usually occur from day to night time. At night, seawater rises to the ground, crashing and scavenging the field and waterways. Not only the house but several graves in the public cemetery area of Karangharjo Village, Kragan Subdistrict, Rembang City, were damaged by being hit by big waves so that the condition of the graves were getting worse, some were even missing due to the onslaught of the waves, resulting in abrasion. Figure 1 showed the damage to houses and graves due

to abrasion.

Figure 1. Damage to houses, eroded beaches, and damage to graves

The onslaught of every strong wave, which causes the coast to be eroded, is known as coastal erosion or abrasion (Figure 2). The results of the beach's scouring are carried to the sea, and the sea waves will continue to erode according to the strength of the wind, wind direction, and the strength of the wind movement that carries the movement on the sea surface. The impact of the crashing waves will always get worse when it enters the eastern wind season.

Various attempts were made to resist the waves of seawater. A temporary effort was made by piling sandbags on the beach along a residential area. Moreover, the government is seeking funds for longterm management to save the residential environment of residents. Local fishers are worried that if embankments are made, they cannot moor their boat. Therefore, it is necessary to make a suitable coastal embankment to moor their boats.

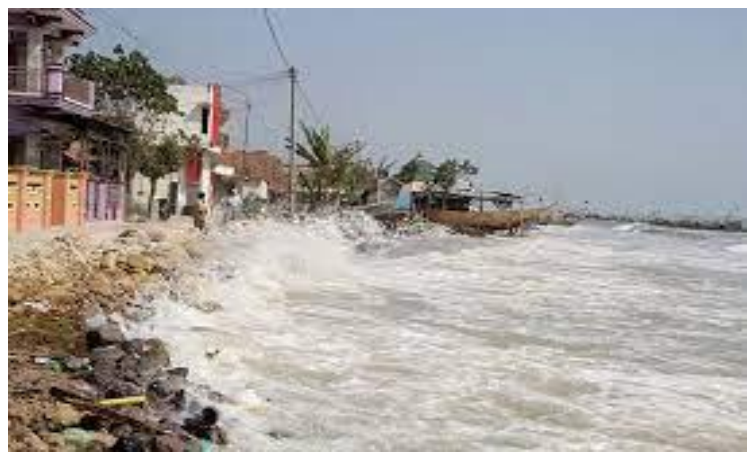

Figure. 2. The condition of eroded beach is called beach erosion or abrasion

An abrasion is an event with a high level of risk, so it requires serious handling that does not erode coastal areas near residential areas. The Rembang Regency Government has made efforts to build a wave barrier in Kragan Village in an 80-meter long concrete riprap. One way that can be done to minimize the risk of abrasion is mitigation, namely structural mitigation, and non-structural mitigation. Structural mitigation is an effort to reduce disaster risk through physical development by making concrete riprap, gabions, embankments, and the like. On the other hand, nonstructural mitigation is carried out by increasing the capacity of the community, for example, conducting socialization, simulations, and others. Structural mitigation efforts by making physical buildings are 
primarily carried out for abrasion handling in several regions in Indonesia [13].

Rembang Regency, as one of the areas with a high risk of abrasion, has implemented several forms of structural mitigation. According to [13], structural abrasion barrier mitigation can be done through mechanical and vegetative means. Structural mitigation efforts are being executed by arranging limestone rocks on the coast of Rembang. Another form of abrasion barrier found in Rembang Regency is a concrete pipe. The structural method by mechanical means of this concrete pipe model is rarely used in other areas in Indonesia because, in general, concrete pipes function as culverts in residential areas. Installation of concrete pipes is done by digging a little $(>50 \mathrm{~cm})$ of soil in the coastal area and planting concrete pipes in the excavated hole. The hollow concrete pipe is filled with soil which functions as a load so that the waves do not easily knock it over. Concrete pipes are usually installed in areas that have a typology of muddy beaches. The description of concrete pipes in Rembang Regency can be seen in Figure 3.

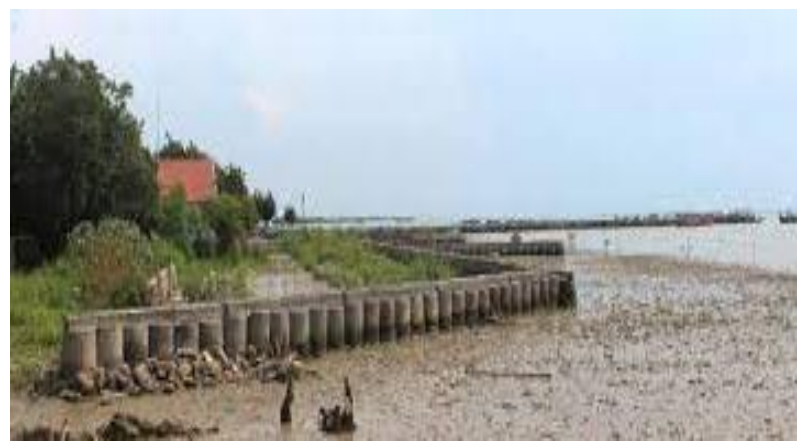

Figure 3. An abrasion resistant barrier in the form of a concrete pipe [13]

\subsection{The Role of KSB in Handling and Adaptation of Abrasion Disaster in Kragan Village}

According to Head Regulation No. 1 BNPB on General Guidelines for Disaster Resilient Villages and Sub-Districts (2012), Disaster Preparedness Group / Disaster Risk Reduction Groups or Disaster Management Volunteer Teams are the village level groups that play a vital role as the pioneers or drivers of disaster risk reduction activities. The Disaster Preparedness Group (KSB) was formed by BPBD, which is expected to be the extended hand of the government in implementing disaster management. The Disaster Preparedness Group is an organization whose members come from the community. The government (BPBD) recommended that the community partake in implementing policies or in dealing with public problems.
The role of KSB during the pre-disaster period was to provide socialization and education to the community. The activities of KSB in assisting the community provide much understanding regarding the risk of abrasion disasters, the impacts caused by abrasion, and the precaution to minimize the risk of abrasion disasters. However, this activity still encountered obstacles, so that it has yet to be effective. The obstacles include the absence of operational funds for activities owned by the Disaster Preparedness Group, lack of supporting facilities and infrastructure for activities, the behavior of some members who do not care, and the living condition of the people in the area. The community also plays a role in coastal management through self-help in reclamation and handling of coastal damage by planting various plants that inhibit the rate of abrasions, such as pandanus, coastal cottonwood (waru), and purple coral tree (canging) [14].

KSB programs that exist, among others, are dissemination of disaster response, picket guard posts, predicting disaster threats, training, providing information and disseminating information on disaster threats, and holding meetings with local communities regarding disaster management [14]. The formation of KSB has the main objective of forming a disaster response community, meaning that the community is more prepared and resilient in facing all kinds of disaster threats. The Disaster Preparedness Group has several task forces or working groups, including the Early Warning Task Force, the First Aid Task Force, the Evacuation and Rescue Task Force, the Logistics Task Force, and the Security Task Force.

The role of KSB is evident in three aspects, namely the communication aspect, the evacuation aspect, and the shared kitchen. However, the role of the Disaster Preparedness Group in the knowledge and attitude of flood disaster preparedness has yet to be appropriately implemented. The unsuccessful implementation follows an interview with the KSB, who admitted that they had not conducted training and outreach to residents directly. This statement was supported by the results of interviews with residents who claimed not to know about the KSB activities and did not know about any training or outreach to residents and the results of the knowledge tests that were only in the 'good enough' category. Community knowledge and attitudes were gained from personal experience during a disaster and learning experiences from education, television, or social media. The Disaster Preparedness Group has obstacles and constraints that prevent their role from being carried out properly, namely the lack of funds, facilities, human resources, and low awareness of residents about disasters. 
In detail, these obstacles consist of the absence of operational funds for the Disaster Preparedness Group's activities, the absence of supporting facilities and infrastructure for activities, the existence of conditions where some members do not care, and the condition of the people in the area. The Disaster Preparedness Group is a partner of BPBD in disaster risk reduction. The following is an explanation of forming $\mathrm{KSB}$ based on several stages (Figure 4).

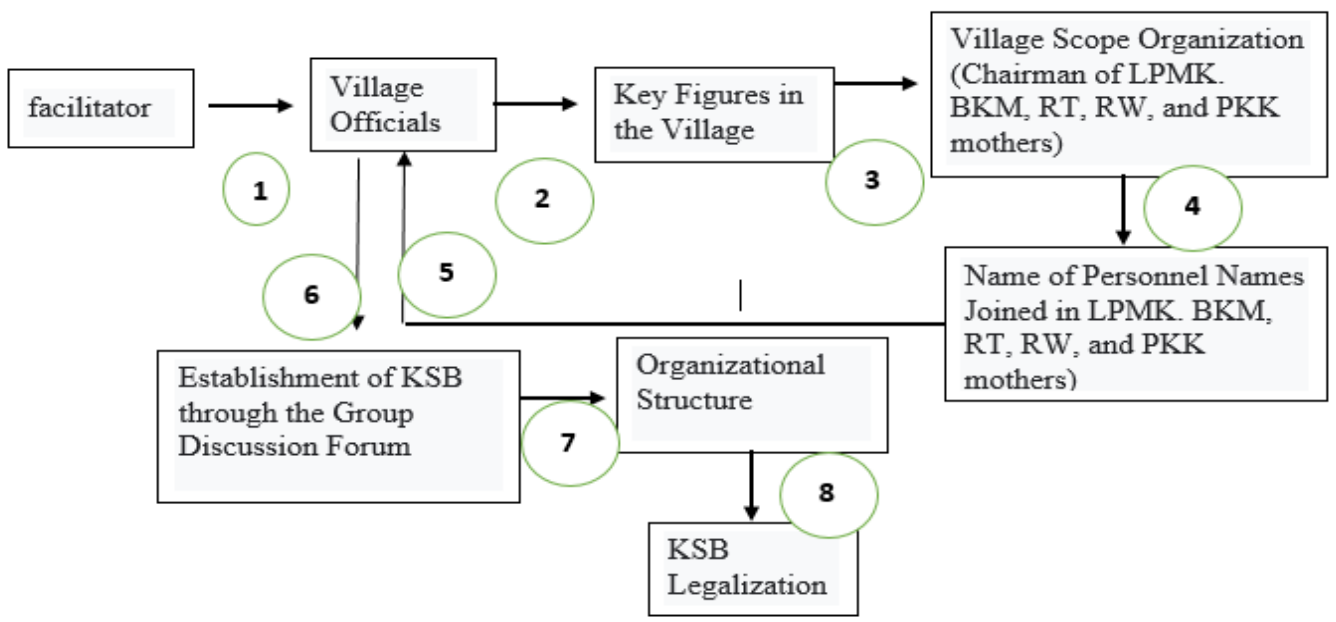

Information:

Figure 4. The process of establishing KSB [12]

1. The facilitator conducts interviews to find critical figures

2. Sub-district officials provide information on critical figures, as sources

3. The critical figures come from sub-district organizations (Head of LPMK, BKM, RW, RT, PKK women)

4. The critical figures provide information on the names to be invited in a focus group discussion to establish KSB

5. The facilitator verifies the sub-district officials

6. Focus group discussion on the establishment of KSB

7. Arranging KSB organizational structure

8. Legalized KSB with District and Sub-District Decree.

\section{CONCLUSION}

The abrasion disaster in Kragan Village needs special attention. Moral and material assistance must continue to be carried out by the community in various ways. Adaptation is a reasonable effort for the community in the area. The existence of KSB as a companion to abrasion-prone communities plays a vital role in realizing community preparedness for abrasion disasters. KSB becomes a bridge between the government and the community. They are expected to disseminate information and provide preparedness training from the government to the surrounding community. However, they also face various obstacles, especially funding, infrastructure, and community participation.

\section{REFERENCES}

[1] Amri, M. R., Yulianti, G., Yunus, R., Wiguna, S., Adi, A. W., Ivhwana, A. N., Radongkir, R. E., \& Septian, R. T. (2016). Risiko Bencana Indonesia. Badan Nasional Penanggulangan Bencana.

[2] BPBD Kabupaten Rembang. (2019). Rencana Strategis BPBD Kabupaten Rembang 2016-2021. Badan Penanggulangan Bencana Daerah Kabupaten Rembang.

[3] Ali, M. S. S., Arsyad, M., Kamaluddin, A., Busthanul, N., \& Dirpan, A. (2019). Community based disaster management: Indonesian experience community based disaster management : Indonesian experience. Earth and Environmental Science, 1-9. https://doi.org/10.1088/1755-1315/235/1/012012.

[4] Shaw, R., Takeuchi, Y., Gwee, Q. R., \& Shiwaku, K. (2015). Disaster Education: An Introduction. Community, Environment and Disaster Risk Management, $7, \quad 1-22$ https://doi.org/10.1108/S20407262(2011)0000007007.

[5] Nifa, F. A. A., Abbas, S. R., Lin, C. K., \& Othman, S. N. (2017). Developing a disaster education program for community safety and resilience: The preliminary phase. AIP Conference Proceedings, 1891, 1-7. https://doi.org/10.1063/1.5005338.

[6] Septikasari, Z. (2018). Strategi Integrasi Pendidikan Kebencanaan Dalam Optimalisasi Ketahanan Masyarakat Menghadapi Bencana Erupsi Gunung Merapi. Jurnal Ketahanan Nasional, 24(1), 47-59. https://doi.org/http://dx.doi.org/ 10.22146/jkn.33142.

[7] Andrea, B., \& Michele, M. (2016). Influence Rather than Control: A New Approach for Disaster 
Education in The Immediate Aftermath of a Disaster. International Journal of Disaster Risk Reduction, 19, 112-117. https://doi.org/10.1016/j.ijdrr.2016.08.026.

[8] Frankenberg, E., Sikoki, B., Sumantri, C., Suriastini, W., \& Thomas, D. (2013). Education, Vulnerability, and Resilience after a Natural Disaster. Ecology and Society: A Journal of Integrative Science for Resilience and Sustainability, 18(2), 16-28. https://doi.org/10.5751/ES-05377-180216.

[9] Hoffmann, R., \& Muttarak, R. (2017). Learn From the Past, Prepare for the Future: Impacts of Education and Experience on Disaster Preparedness in the Philippines and Thailand. World Development, 96, 32-51. https://doi.org/10.1016/j.worlddev.2017.02.016.

[10] Suharini, E., Meliana, D. P., Sanjoto, T. B., \& Kurniawan, E. (2019). The Strategy of Disaster Mitigation Literacy through Problem-Based Learning (PBL) in the School Prone to Tidal Floods. https://doi.org/10.4108/eai.18-7-2019.2290156.

[11] Setyowati, D. L., Mohamad Amin, Tri Marhaeni Puji Astuti, and Ishartiwi. 2017. Community Efforts For Adaptation and Anticipate To Flood Tide (ROB) In Bendono Village, District Sayung Demak, Central Java, Indonesia. Man in India, Vol 97(5): 241-252.

[12] Handayani, W., Yesiana, R., \& Anggraini, M. (2018). Pembentukan Dan Penguatan Kelompok Siaga Bencana (KSB) Sebagai Wujud Kesiapsiagaan Masyarakat Terhadap Banjir Di Kanal Banjir Barat Kota Semarang. Jurnal Riptek, 12(1), 113-128.

[13] Maulana, E., Wulan, T. R., Wahyuningsih, D. S., Mahendra, I. W. W. Y., \& Siswanti, E. (2016). Strategi pengurangan risiko abrasi di pesisir Kabupaten Rembang, Jawa Tengah. Proseding Seminar Nasional Geografi UMS.

[14] Napitupulu, F. S., Subowo, A., \& Afrizal, T. (2021). The Role of Stakeholderss In Poverty Alleviation Of Fisherman Groups In Tanjung Mas Urban Village, North Semarang Sub-District, Semarang City. Journal of Public Policy and Management Review, 10(2), 259-517. DOI: $\underline{10.14710 / j p p m r . v 10 i 2.30661}$ 